Tetrahedron Letters

journal homepage: www.elsevier.com

\title{
Towards the construction of dermatan sulfate (DS) partial disaccharide library: efficient synthesis of building blocks, common intermediate, and ligand conjugate of type-B DS disaccharide
}

\author{
Yuhei Kaitsubata, ${ }^{\mathrm{a}}$ Rikiya Aramaki, ${ }^{\mathrm{a}}$ Kyosuke Nishioka, ${ }^{\mathrm{a}}$ Masahiro Wakao, ${ }^{\mathrm{a}} *$ Yasuo Suda ${ }^{\mathrm{a}, \mathrm{b}}$ \\ ${ }^{a}$ Department of Chemistry, Biotechnology, and Chemical Engineering, Graduate School of Science and Engineering, Kagoshima University, 1-21-40 \\ Kohrimoto, Kagoshima 890-0065, Japan \\ ${ }^{b}$ SUDx-Biotec Corporation, 1-42-1 Shiroyama, Kagoshima 890-0013, Japan
}

\section{ARTICLE INFO}

\section{Article history:}

Received

Received in revised form

Accepted

Available online

\section{Keywords:}

Dermatane sulfate

Synthesis

Library

glycosaminoglycan

\section{ABSTRACT}

\begin{abstract}
Dermatan sulfate (DS) is composed of a repeating disaccharide unit containing iduronic acid (IdoA) and $N$-acetylgalactosamine (GalNAc). In the divergent synthesis of DS disaccharide, it is important to prepare the IdoA moiety with a diverse set of protecting groups. IdoA was efficiently obtained from glucose in 20 steps with some modifications following the method reported by van Boeckel et al. A disaccharide building block for constructing the DS disaccharide was synthesized by the glycosylation of the designed IdoA moiety with GalNAc. The disaccharide building block was used in the synthesis of DS-B disaccharide and its ligand conjugate.
\end{abstract}

2009 Elsevier Ltd. All rights reserved.
Dermatan sulfate (DS) is a sulfated polysaccharide, belonging to glycosaminoglycan (GAG) superfamily such as chondroitin sulfate (CS), heparan sulfate (HS), and heparin (HP). DS usually binds to a core protein and forms the corresponding glycoprotein, namely, DS-proteoglycan (DS-PG). DS-PG is a component of cell surface and extracellular matrix and interacts with many bioactive proteins such as cell surface receptors, growth factors, and cytokines to regulate their activity. ${ }^{1-7}$ The structure of DS consists of repeating disaccharide units containing iduronic acid (IdoA) and $N$-acetylgalactosamine (GalNAc). However, a DS polysaccharide chain is in fact heterogeneous and has various sugar and sulfation patterns because it is biologically synthesized from chondroitin $(\mathrm{CH})$ or a $\mathrm{CS}$ chain by random enzymatic modification such as C-5 epimerization and O-sulfation. ${ }^{8,9}$ Recently, the specific microdomain structure in a DS polysaccharide chain has been considered to be very important for the expression of DS biofunction;10 structurally defined DS oligosaccharides are eager for elucidating the structure-function relationship of DS at the molecular level. Although many methods have been reported for the synthesis of DS and CS oligosaccharides, ${ }^{11-21}$ it is still challenging to design building blocks for the efficient synthesis of their oligosaccharides with a diverse set of sulfation patterns, because the previous methods are not suitable for library synthesis. In this study, we report the efficient synthesis of a DS disaccharide building block and its usage for the preparation of ligand conjugates of DS disaccharide structure towards construction of a DS disaccharide library.
For the synthesis of DS disaccharide structures based on a combinatorial approach, a disaccharide building block 1 was designed. Building block $\mathbf{1}$ has orthogonally removable protecting groups at the sulfated and glycosidic positions. Because the 3-O-sulfated structure on uronic acid (UroA) has been discovered in a CS chain obtained from lower marine organisms $^{22}$ but not yet in a DS chain, the building block was designed by considering all the possible 16 types of DS disaccharide structures. DS ligand conjugates (Figure 1) were selected to fabricate "Sugar Chips",20,21,23,24 and investigate the binding properties of GAG-binding protein using a surface plasmon resonance (SPR) biosensor.

First, the monosaccharide moiety was synthesized as shown in Scheme 1. GalNTroc $\mathbf{3}^{20}$ was synthesized from galactosamine hydrochloride in three steps using easily manipulated protecting groups $^{20}$ : The amino group was protected with a triethoxy carbonyl (Troc) group, the anomeric position was protected with an allyl group, and the $\mathrm{OH}$ groups at the 4- and 6-positions were protected with a benzylidene group.

IdoA 15 was synthesized from D-glucose as the starting material following the method reported by van Boeckel et al. ${ }^{25}$ with slight modifications. D-Glucose was converted to diisopropylidene glucofuranose, and the remaining $\mathrm{OH}$ group at the 3-position was protected with a $p$-nitrobenzyl (PNB) group. ${ }^{26}$ 3-O-PNB 5 was converted into monomesylate $\mathbf{6}$ via the selective removal of the 5,6-isopropylidene group, followed by 5,6 -di- $O$ -

* Corresponding author. Tel.: +81-99-285-7843; fax: +81-99-285-7856; e-mail: wakao@eng.kagoshima-u.ac.jp 


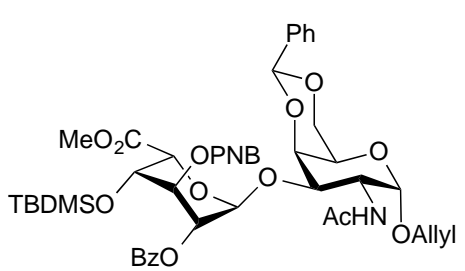

disaccharide building block 1

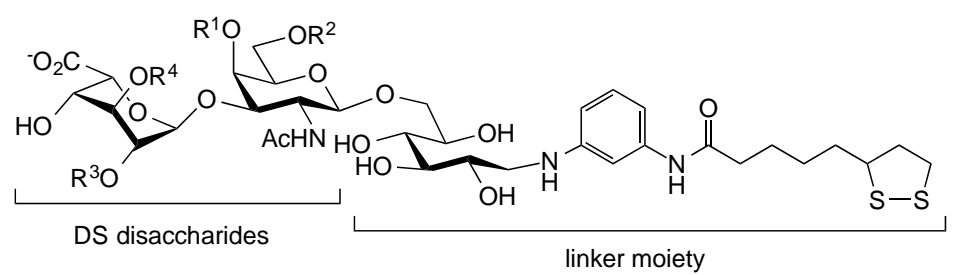

DS ligand conjugates, $\mathrm{R}^{1}=\mathrm{R}^{2}=\mathrm{R}^{3}=\mathrm{R}^{4}=\mathrm{H}$ or $\mathrm{SO}_{3}{ }^{-}$

Figure 1. Designed disaccharide building block $\mathbf{1}$ and target DS ligand conjugates

mesylation and 6-O-acetylation. Epoxide 7 was synthesized from monomesylate 6 using $t$-BuOK as the base in a mixture of $\mathrm{CH}_{2} \mathrm{Cl}_{2} / t-\mathrm{BuOH}(1: 10 \mathrm{v} / \mathrm{v})$. The PNB group could not be removed under this condition. Epoxide 7 was converted into tetraacetate $\mathbf{8}$ after acidic hydrolysis with TFA and acetylation. The anomeric position was then protected with an allyl group by the glycosylation with (allyloxy)trimethylsilane (AllylOTMS) in the presence of $\mathrm{SnCl}_{4}$. The de- $O$-acetylation was performed with aqueous $\mathrm{NH}_{3}$ under mild basic conditions because the PNB group is unstable under strong basic conditions such as MeONa. pMethoxybenzylidenation of the resulting compound afforded $p$ methoxybenzylidene 10. Benzoylation at the 2-position, followed by the reductive ring opening of the $p$-methoxybenzylidene group with TFA and $\mathrm{NaBH}_{3} \mathrm{CN}^{27}$ afforded 4-OH compound 12. After the silylation of the 4-OH group with tert-butyldimethylsilyl triflate (TBDMSOTf) and triethylamine (TEA), the $p$ methoxybenzyl (MPM) group was removed with 2,3-dichloro5,6-dicyano- $p$-benzoquinone (DDQ), affording 6-OH compound
13. Oxidation of the 6-position of $\mathbf{1 3}$ with $(2,2,6,6-$ tetramethylpiperidin-1-yl)oxyl (TEMPO) and $\mathrm{NaOCl}$, followed by methyl esterification with trimetylsilyldiazomethane afforded a fully protected IdoA 14. Deprotection of the allyl group of IdoA 14 furnished 1-OH derivative 15, which can is used as a glycosyl donor after conversion to an imidate.

With both the glycosyl donor and acceptor moieties in hand, disaccharide building block $\mathbf{1}$ and trisaccharide intermediate 21 were synthesized (Scheme 2). After conversion of 1-OH derivative $\mathbf{1 5}$ to glycosyl imidate 16, the glycosylation of GalNTroc acceptor $\mathbf{4}$ with IdoA donor $\mathbf{1 6}$ was performed with TMSOTf, affording the desired building block 1 in $69 \%$ yield. Stereochemistry of the anomeric position was confirmed by NMR analysis; it was determined to be the $\square$-anomer ( $\square 5.28$ ppm, brs). Disaccharide 1 was then converted to disaccharide donor $\mathbf{1 8}$ by the deprotection of the allyl group, followed by the $\begin{array}{lllllllllll} & \mathrm{r} & \mathrm{e} & \mathrm{a} & \mathrm{t} & \mathrm{m} & \mathrm{e} & \mathrm{n} & \mathrm{t}\end{array}$

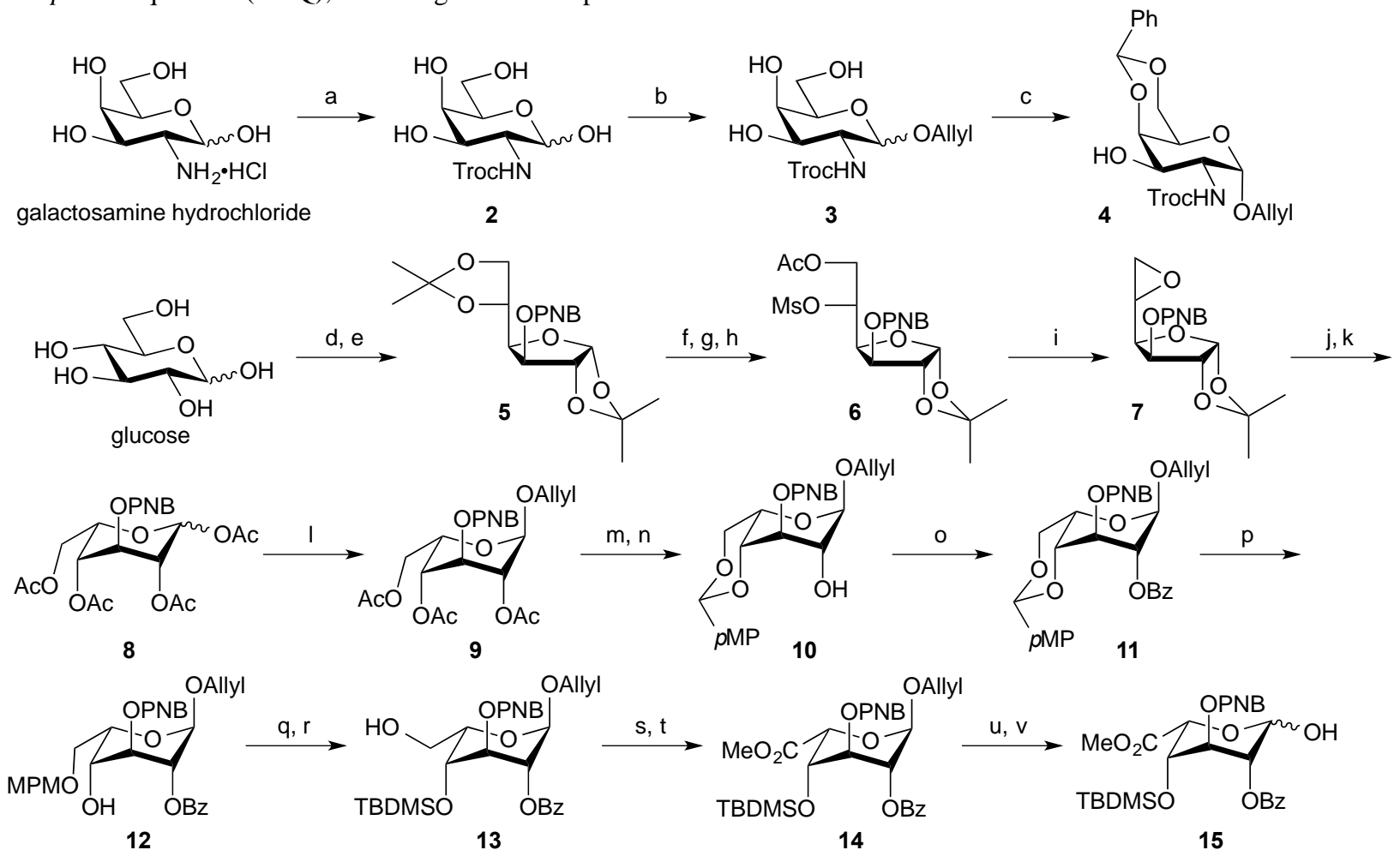

Scheme 1. Syntheses of GalNAc 4 and IdoA 15. (a) TrocCl, $\mathrm{NaHCO}_{3}$ in $\mathrm{H}_{2} \mathrm{O}, 0{ }^{\circ} \mathrm{C}$; (b) AllylOH, Dowex $50 \mathrm{~W}-\mathrm{X} 8$ ( $\mathrm{H}^{+}$), reflux; (c) $\mathrm{PhCH}(\mathrm{OMe})_{2}, \mathrm{CSA}$ in $\mathrm{CH}_{3} \mathrm{CN}, 66 \%$ yield ( $\square$ only, three steps); (d) $\mathrm{H}_{2} \mathrm{SO}_{4}$ in acetone, $44 \%$ yield; (e) $\mathrm{PNBBr}_{2} \mathrm{Ag}_{2} \mathrm{O}, \mathrm{MS}_{4} \mathrm{~A}$ in $\mathrm{Et}{ }_{2} \mathrm{O}$, $94 \%$ yield; (f) $60 \% \mathrm{AcOH}$ aq., $40{ }^{\circ} \mathrm{C}$; (g) $\mathrm{MsCl}$ in pyridine, $0{ }^{\circ} \mathrm{C}$; (h) $\mathrm{AcOK}, 18$-crown- 6 in $\mathrm{CH}_{3} \mathrm{CN}$, reflux, 53\% yield (three steps); (i) $t$-BuOK in $t$ - $\mathrm{BuOH} / \mathrm{CH}_{2} \mathrm{Cl}_{2}(10: 1 \mathrm{v} / \mathrm{v}), 40{ }^{\circ} \mathrm{C}$; (j) TFA aq.; (k) $\mathrm{Ac}_{2} \mathrm{O}$ in pyridine, $66 \%$ yield (three steps); (1) AllylOTMS, SnCl 4 , MS 4A in $\mathrm{CH}_{2} \mathrm{Cl}_{2},-18{ }^{\circ} \mathrm{C}, 86 \%$ yields; (m) $\mathrm{NH}_{3}$ aq. in $\mathrm{MeOH}, 0{ }^{\circ} \mathrm{C}$; (n) $p$-MeO-PhCH(OMe) ${ }_{2}, \mathrm{CSA}$ in $\mathrm{CH}_{3} \mathrm{CN}, 67 \%$ yield (two steps); (o) $\mathrm{BzCl}$ in pyridine, $95 \%$ yield; (p) TFA, $\mathrm{NaBH}_{3} \mathrm{CN}$, MS 4A in DMF, 72\% yield; (q) TBDMSOTf, TEA, MS 4A in $\mathrm{CH}_{2} \mathrm{Cl}_{2}$; (r) DDQ, $\mathrm{H}_{2} \mathrm{O}$ in $\mathrm{CH}_{2} \mathrm{Cl}_{2}, 92 \%$ yield (two steps); (s) TEMPO, $\mathrm{NaHCO}_{3}, \mathrm{KBr}, \mathrm{NaOCl}, \mathrm{H}_{2} \mathrm{O}$ in $\mathrm{CH}_{3} \mathrm{CN}, 0{ }^{\circ} \mathrm{C}$; (t) $\mathrm{TMSCHN}_{2}$ in $\mathrm{MeOH}, 0{ }^{\circ} \mathrm{C}, 95 \%$ yield (two steps); (u) $\mathrm{Ir}\left[(\mathrm{COD})\left(\mathrm{PMePh}_{2}\right)_{2}\right] \mathrm{PF}_{6}, \mathrm{H}_{2}$ in THF; (v) $\mathrm{H}_{2} \mathrm{O}, \mathrm{I}_{2}$ in THF, $90 \%$ yield (two steps). 

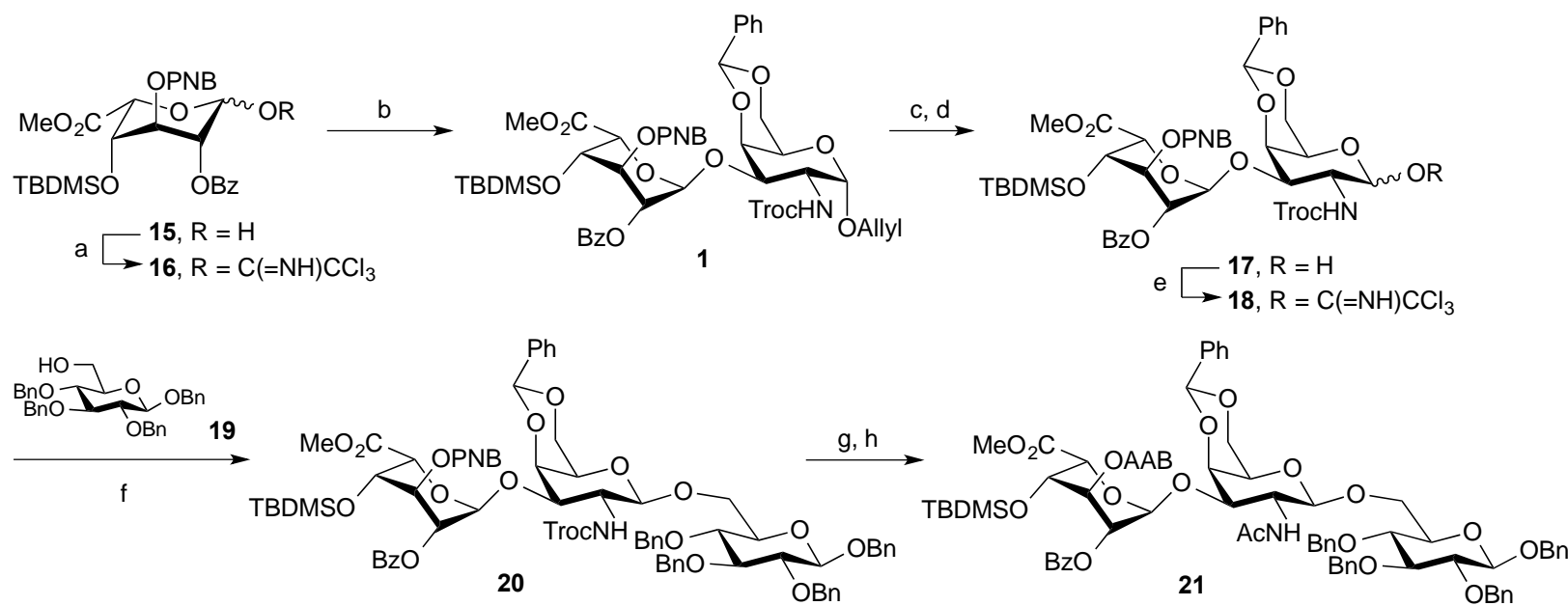

Scheme 2. Synthesis of DS trisaccharide intermediate 21. (a) $\mathrm{CCl}_{3} \mathrm{CN}, \mathrm{Cs}_{2} \mathrm{CO}_{3}$ in $\mathrm{CH}_{2} \mathrm{Cl}_{2}$; (b) 4, TMSOTf, $\mathrm{MS} 4 \mathrm{~A}$ in $\mathrm{CH}_{2} \mathrm{Cl}_{2}, 69 \%$ yield (two steps); (c) $\operatorname{Ir}\left[(\mathrm{COD})\left(\mathrm{PMePh}_{2}\right)_{2}\right] \mathrm{PF}_{6}, \mathrm{H}_{2}$ in THF; (d) $\mathrm{H}_{2} \mathrm{O}, \mathrm{I}_{2}$ in THF, 95\% yield (two steps) (e) $\mathrm{CCl}_{3} \mathrm{CN}_{2} \mathrm{Cs}_{2} \mathrm{CO}_{3}$ in $\mathrm{CH}_{2} \mathrm{Cl}_{2}$.; (f) TMSOTf, MS 4A in $\mathrm{CH}_{2} \mathrm{Cl}_{2},-78{ }^{\circ} \mathrm{C}, 77 \%$ yield (two steps); (g) $\mathrm{Zn}-\mathrm{Cu}$ couple in $\mathrm{AcOH}$; (h) $\mathrm{A}_{2} \mathrm{O}$ in pyridine, $94 \%$ yield (two steps).

with $\mathrm{CCl}_{3} \mathrm{CN}$. The glycosylation of donor 18 with glucose $\mathbf{1 9}$, acting as the hydrophilic reaction site to prepare the ligand conjugate for the immobilization of disaccharide structure on the sensor chip of SPR biosensor, afforded trisaccharide $\mathbf{2 0}$. Trisaccharide intermediate $\mathbf{2 1}^{28}$ was synthesized by the reduction of the $\mathrm{NO}_{2}$ group on PNB and Troc group on GalNTroc moiety, followed by $N$-acetylation.

Next, the orthogonal deprotection, selective sulfation, and conjugation of linker $\mathbf{2 8}$ were investigated (Scheme 3). Selective cleavage of the benzylidene group at the 4,6-position on GalNAc was achieved with a combination of $\mathrm{TfOH} / \mathrm{Et}_{3} \mathrm{SiH}$, $\mathrm{PhBCl}_{2} / \mathrm{Et}_{3} \mathrm{SiH}$, and $\mathrm{TFA} / \mathrm{H}_{2} \mathrm{O}$, affording $4^{\prime}-\mathrm{OH}$ compound 22, $6^{\prime}-\mathrm{OH}$ compound $\mathbf{2 3}$, and 4',6'-OH compound 24, respectively. For the deprotection of AAB group, DDQ was effective, affording $3^{\prime \prime}-\mathrm{OH}$ compound $\mathbf{2 5}$ in a moderate yield. The TBDMS group was removed by treating with HF.pyridine, which was suitable for both nonsulfated and sulfated compounds. Moreover, DS-B disaccharide ligand conjugate $\mathbf{2 9}$ was synthesized. Hydrolysis of the $\mathrm{Bz}$ group and methyl ester of compound 22, followed by the sulfation of the free $\mathrm{OH}$ group with an excess amount of $\mathrm{SO}_{3}$.pyridine afforded the corresponding disulfated compound. After the desilylation, the final deprotection of the benzyl group was achieved by hydrogenolysis with $\mathrm{Pd} / \mathrm{C}$ under 7 $\mathrm{kg} / \mathrm{cm}^{2} \mathrm{H}_{2}$ pressure. Sulfate 28 was then converted to ligand conjugate $\mathbf{2 9}^{29}$ in a good yield following the method reported previously. ${ }^{20}$ Other sulfated dermatan disaccharides can be prepared by appropriate deprotection and sulfation. ${ }^{24}$

In conclusion, a novel disaccharide building block 1 was designed for constructing a DS oligosaccharide library, possessing orthogonally removable protecting groups and capable of generating diverse sulfation patterns. DS disaccharide

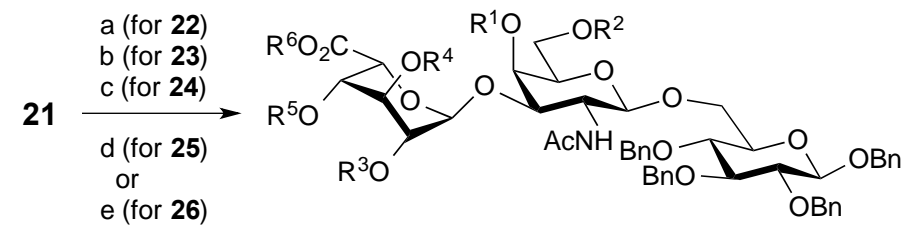

22, $R^{1}=H, R^{2}=B n, R^{3}=B z, R^{4}=A A B, R^{5}=T B D M S, R^{6}=M e$ 23, $R^{1}=B n, R^{2}=H, R^{3}=B z, R^{4}=A A B, R^{5}=T B D M S, R^{6}=M e$ 24, $\mathrm{R}^{1}=\mathrm{H}, \mathrm{R}^{2}=\mathrm{H}, \mathrm{R}^{3}=\mathrm{Bz}, \mathrm{R}^{4}=\mathrm{AAB}, \mathrm{R}^{5}=\mathrm{TBDMS}, \mathrm{R}^{6}=\mathrm{Me}$ 25, $R^{1}=R^{2}=$ benzylidene, $R^{3}=B z, R^{4}=H, R^{5}=T B D M S, R^{6}=M e$ 26, $R^{1}=R^{2}=$ benzylidene, $R^{3}=B z, R^{4}=A A B, R^{5}=H, R^{6}=M e$
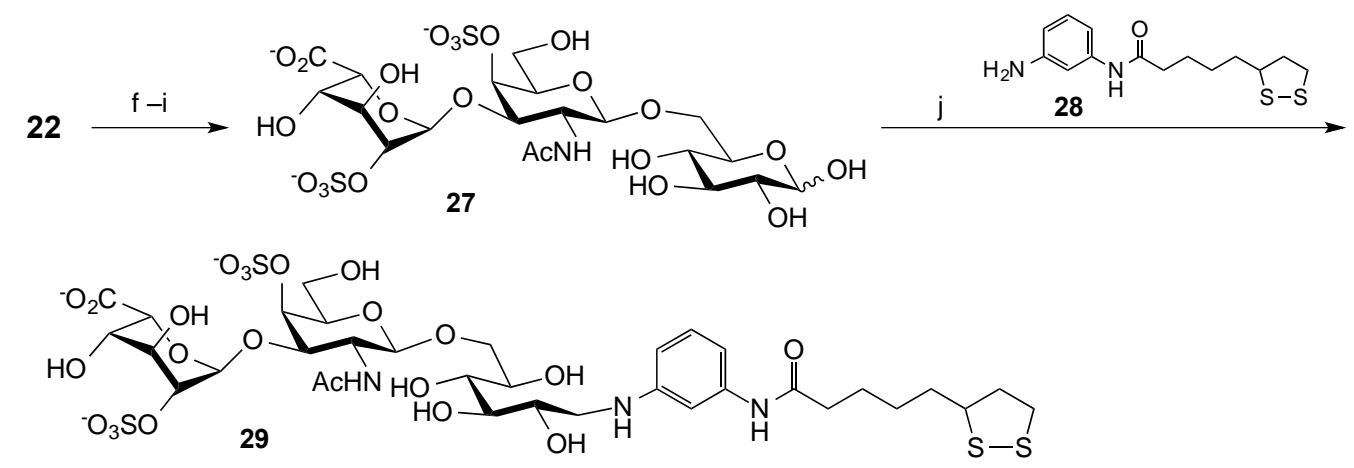

Scheme 3. Selective deprotection of trisaccharide intermediate 21 and conversion to DS-B disaccharide ligand conjugates. (a) TfOH, $\mathrm{Et}_{3} \mathrm{SiH}$, MS 4A in $\mathrm{CH}_{2} \mathrm{Cl}_{2}, 88 \%$ yield; (b) $\mathrm{PhBCl}_{2}, \mathrm{Et}_{3} \mathrm{SiH}$, MS $4 \mathrm{~A}$ in $\mathrm{CH}_{2} \mathrm{Cl}_{2},-78{ }^{\circ} \mathrm{C}, 92 \%$ yield; (c) TFA/ $\mathrm{H}_{2} \mathrm{O}$ (1:1 v/v), $86 \%$ yield; (d) DDQ, $\mathrm{H}_{2} \mathrm{O}$ in $\mathrm{CH}_{2} \mathrm{Cl}_{2}, 69 \%$ yield; (e) HF.pyridine in pyridine; (f) $\mathrm{LiOH}, \mathrm{H}_{2} \mathrm{O}, \mathrm{H}_{2} \mathrm{O}_{2}$ in THF/MeOH/H $/ 2 \mathrm{O}(5: 5: 1 \mathrm{v} / \mathrm{v} / \mathrm{v})$, then $4 \mathrm{M} \mathrm{NaOH}$ (one-pot reaction); (g) $\mathrm{SO}_{3}$.pyridine in pyridine; (h) HF.pyridine in pyridine; (i) $10 \% \mathrm{Pd} / \mathrm{C}, \mathrm{H}_{2}\left(7 \mathrm{~kg} / \mathrm{cm}^{2}\right) \mathrm{in} \mathrm{H}_{2} \mathrm{O} / \mathrm{MeOH} / \mathrm{AcOH}(5: 5: 1$ $\mathrm{v} / \mathrm{v} / \mathrm{v}) ;(\mathrm{j}) \mathrm{NaBH}_{3} \mathrm{CN}$ in $\mathrm{H}_{2} \mathrm{O} / \mathrm{DMAc} / \mathrm{AcOH}(5: 5: 1 \mathrm{v} / \mathrm{v} / \mathrm{v}), 28 \%$ yield (six steps). 
building blocks 1 were efficiently synthesized using appropriate IdoA and GalNAc moieties. IdoA, which is a key monosaccharide for the disaccharide building block, was efficiently synthesized from glucose in 20 steps. DSdisaccharides were systematically and divergently synthesized from trisaccharide intermediate 21. Although further studies are needed to construct a DS disaccharide library, the designed DS disaccharides may be useful for the synthesis of versatile DS and DS/CS hybrid oligosaccharides with minimal derivatization.

\section{Acknowledgements}

This study was financially supported in part by grants from the Ministry of Education, Culture, Sports, Science and Technology (MEXT) (Grant-in-Aid for Young Scientists B, Kakenhi 21710233 to MW and Grant-in-Aid for Scientific Research B, Kakenhi 23300356 to YS), Japan Science and Technology Agency (JST) (A-Step, Post-venture Support, AS2416907P to YS), and Japan Ministry of Health, Labor and Welfare (Nano-Medicine, H21-nano-ippan-002 to YS).

\section{References and notes}

1. Linhardt, R. J.; Hileman, R. E. Gen. Pharm. 1995, 26, 443451.

2. Trowbridge, J. M.; Gallo, R. L. Glycobiology 2002, 12, $117 \mathrm{R}-125 \mathrm{R}$.

3. Sugahara, K.; Mikami, T. Curr. Opin. Struct. Biol. 2007, 17, 536-545.

4. Gandhi, N. S.; Mancera, R. L. Chem. Biol. Drug Des. 2008, 72, 455-482.

5. Yamada, S.; Sugahara, K. Curr. Drug Disc. Technol. 2008, 5, 289-301.

6. Volpi, N. Carbohydr. Polymers 2010, 82, 233-239.

7. Thelin, M. A.; Bartolini, B.; Axelsson, J.; Gustafsson, R.; Tykesson, E.; Pera, E.; Oldberg, A.; Maccarana, M.; Malmstrom, A. FEBS J. 2013, 280, 2431-2446.

8. Sugahara, K.; Mikami, T.; Uyama, T.; Mizuguchi, S.; Nomura, K.; Kitagawa, H. Curr. Opin. Struct. Biol. 2003, 13, 612-620.

9. Silbert, J. E.; Sugumaran, G. IUBMB Life 2002, 54, 177186.

10. Osborne, S. A.; Daniel, R. A.; Desilva, K.; Seymour, R. B. Glycobiology 2007, 18, 225-234.

11. Jacquinet, J.-C.; Sinaÿ, P. Carbohydr. Res. 1987, 159, 229253.

12. Marra, A.; Xia, D.; Petitou, M.; Sinaÿ, P. Carbohydr. Res. 1989, 195, 39-50.

13. Uzawa, H.; Gerz, M.; Ito, Y.; Ogawa, T. Carbohydr. Lett. 1996, 2, 197-204.

14. Rochepeau-Jobron, L; Jacquinet, J.-C. Carbohydr. Res. 1997, 305, 181-191.

15. Barroca, N; Jacquinet, J.-C. Carbohydr. Res. 2000, 329, 667-679.

16. Barroca, N.; Jacquinet, J.-C. Carbohydr. Res. 2002, 337, 673-689.

17. Karst, N. A.; Linhardt, R. J. Curr. Med. Chem. 2003, 10, 1993-2031.
18. Maza, M.; Kayser, M. M.; Macchione, G.; López-Prados, J.; Angulo, J.; de Paz, J. L.; Nieto, P. M. Org. Biomol. Chem. 2013, 42, 3510-3525.

19. Kandasamy, J.; Schuhmacher, F.; Hahm, H. S.; Kleina, J. C.; Seeberger, P. H. Chem. Commun. 2014, 50, 1875-1877.

20. Wakao M.; Obata R.; Miyachi K.; Kaitsubata Y.; Kondo T.; Sakami C.; Suda, Y. Bioorg. Med. Chem. Lett. 2015, 25, 1407-1411.

21. Miyachi K.; Wakao, M.; Suda, Y. Bioorg. Med. Chem. Lett. 2015, 25, 1552-1555.

22. Sugahara, K.; Yamada, S. Trends Glycosci. Glycotechnol. 2000, 12, 321-349.

23. Suda, Y.; Arano, A.; Fukui, Y.; Koshida, S.; Wakao, M.; Nishimura, T.; Kusumoto, S.; Sobel, M. Bioconjugate Chem. 2006, 17, 1125-1135.

24. Wakao, M.; Saito, A.; Ohishi, K.; Kishimoto, Y.; Nishimura, T.; Sobel, M.; Suda, Y. Bioorg. Med. Chem. Lett. 2008, 18, 2499-2504.

25. van Boeckel, C. A. A.; Beetz, T.; Vos, J. N.; de Jong, A. J. M.; van Aelst, S. F.; van den Bosch, R. H. ; Mertens, J. M. R.; van der Vlugt, F. A. J. Carbohydr. Chem. 1985, 4, 293321.

26. Fukase, K.; Tanaka, H.; Torii, S.; Kusumoto, S. Tetrahedron Lett. 1990, 31, 389-392.

27. Johansson, R.; Samuelsson, B. J. Chem. Soc., Perkin Trans. 1 1984, 2371-2374.

28. Trisaccharide intermediate 20: ${ }^{1} \mathrm{H}-\mathrm{NMR}\left(600 \mathrm{MHz}, \mathrm{CDCl}_{3}\right)$ $\delta$ 8.13-7.10 $(35 \mathrm{H}, \mathrm{m}$, aromatic, $\mathrm{NHPh}), 5.85\left(1 \mathrm{H}, \mathrm{d}, J_{N H, 2^{\prime}}=\right.$ $6.8 \mathrm{~Hz}, \mathrm{~N} \underline{\mathrm{H} A c}), 5.52(1 \mathrm{H}, \mathrm{s}, \mathrm{PhC} \underline{\mathrm{H}}), 5.40(1 \mathrm{H}$, brs, H-1"), $5.25(1 \mathrm{H}$, brs, H-2' $), 5.19\left(1 \mathrm{H}, \mathrm{d}, J_{12^{\prime}}=8.8 \mathrm{~Hz}, \mathrm{H}-1^{\prime}\right), 5.19$ $\left(1 \mathrm{H}\right.$, brs, H-5"), 4.91 and 4.69 (each $1 \mathrm{H}, \mathrm{d}, J_{\text {gem }}=10.2 \mathrm{~Hz}$, $\mathrm{PhC}_{2}$ ), 4.89 and 4.69 (each $1 \mathrm{H}, \mathrm{d}, J_{\text {gem }}=10.8 \mathrm{~Hz}, \mathrm{PhC}_{2}$ ), 4.79-4.66 (each $\left.1 \mathrm{H}, \mathrm{d}, J_{\text {gem }}=11.2 \mathrm{~Hz}, \mathrm{PhCH}_{2}\right), 4.82(1 \mathrm{H}$, $\left.\mathrm{dd}, J_{3^{\prime} 4^{\prime}}=J_{3^{\prime} 2^{\prime}}=8.8 \mathrm{~Hz}, \mathrm{H}-3^{\prime}\right), 4.78-4.72\left(3 \mathrm{H}, \mathrm{m}, \mathrm{PhC}_{2}\right.$, $\left.\mathrm{PhC}_{2}, \underline{\mathrm{PhC}}_{2}\right), 4.69-4.66\left(1 \mathrm{H}, \mathrm{m}, \mathrm{PhC}_{2}\right), 4.57$ (1H, d, $J_{l, 2}$ $=8.1 \mathrm{~Hz}, \mathrm{H}-1), 4.37\left(1 \mathrm{H}, \mathrm{d}, J_{6 a, 6 b}=12.2 \mathrm{~Hz}, \mathrm{H}-6 \mathrm{a}\right), 4.28-$ $4.22\left(2 \mathrm{H}, \mathrm{m}, \mathrm{H}-6 \mathrm{a}^{\prime}, \mathrm{H}-4^{\prime}\right), 4.20\left(1 \mathrm{H}, \mathrm{s}, \mathrm{H}-4^{\prime \prime}\right), 4.15(1 \mathrm{H}, \mathrm{d}$, $\left.J_{6 b, 6 a}=12.2 \mathrm{~Hz}, \mathrm{H}-6 \mathrm{~b}\right), 3.89-3.82\left(2 \mathrm{H}, \mathrm{m}, \mathrm{H}-6 \mathrm{~b}^{\prime}, \mathrm{H}-3^{\prime \prime}\right)$, 3.78-3.54 (5H, m, H-2', H-2, H-3, H-4, H-5), 3.58-3.51 $(3 \mathrm{H}, \mathrm{s}, \mathrm{COOMe}), 3.44\left(1 \mathrm{H}, \mathrm{s}, \mathrm{H}-5^{\prime}\right), 0.79(9 \mathrm{H}, \mathrm{s}$, $\left.\mathrm{SiC}\left(\mathrm{CH}_{3}\right)_{3}\right),-0.03 \quad\left(3 \mathrm{H}, \quad \mathrm{s}, \quad \mathrm{Si}\left(\mathrm{CH}_{3}\right)_{2}\right),-0.23 \quad(3 \mathrm{H}, \quad \mathrm{s}$, Si $\left.\left(\mathrm{CH}_{3}\right)_{2}\right)$; HRMS (positive mode) found: $\mathrm{m} / \mathrm{z} 1409.5799$ $[\mathrm{M}+\mathrm{Na}]^{+}$, Calcd for $\mathrm{C}_{78} \mathrm{H}_{90} \mathrm{Cl}_{3} \mathrm{~N}_{2} \mathrm{NaO}_{19} \mathrm{Si}: 1409.5798$.

29. DS-B ligand conjugate: ${ }^{1} \mathrm{H}-\mathrm{NMR}\left(600 \mathrm{MHz}, \mathrm{D}_{2} \mathrm{O}\right) \delta 7.25-$ $7.18(1 \mathrm{H}, \mathrm{m}$, aromatic), 6.97-6.88 $(1 \mathrm{H}, \mathrm{m}$, aromatic $), 6.87-$ $6.77(1 \mathrm{H}, \mathrm{m}$, aromatic), 6.73-6.63 $(1 \mathrm{H}, \mathrm{m}$, aromatic $), 4.90$ (1H, brs, H-1"), 4.45 (1H, d, $\left.J_{1,2}=8.1 \mathrm{~Hz}, \mathrm{H}-1\right), 4.42-4.36$ $\left(1 \mathrm{H}, \mathrm{m}, \mathrm{H}-5^{\prime \prime}\right), 4.21-4.17\left(1 \mathrm{H}, \mathrm{m}, \mathrm{H}-4^{\prime}\right), 4.16\left(1 \mathrm{H}, \mathrm{d}, J_{6 a, 6 b}=\right.$ $7.4 \mathrm{~Hz}, \mathrm{H}-6 \mathrm{a}), 4.04-3.75$ (4H, m, H-2, H-2', H-3", H-2' '), 3.74-3.55 (7H, m, H-3, H-4, H-5, H-6b, H-3', H-5', $\left.\mathrm{CH}_{2} \mathrm{CH}(\mathrm{S}-) \mathrm{CH}_{2^{-}}\right), 3.32-3.24$ (3H, m, H-1a, H-4", H-6a'), 3.06-2.84 (3H, m, H-1b, H-6b', -SC $\underline{\mathrm{H}}_{2} \mathrm{CH}_{2} \mathrm{CH}=$ ), 2.31-2.22 $\left(3 \mathrm{H}, \mathrm{m},-\mathrm{SCH}_{2} \mathrm{CH}_{2} \mathrm{CH}=, \mathrm{NHCOCH}_{2} \mathrm{CH}_{2}-\right), 1.86-1.82(4 \mathrm{H}$, $\left.\mathrm{m}, \mathrm{COCH}_{3},-\mathrm{SCH}_{2} \mathrm{CH}_{2} \mathrm{CH}=\right), 1.61-1.49\left(4 \mathrm{H}, \mathrm{m},-\mathrm{CH}_{2}-\right.$, $\mathrm{CH}_{2^{-}}$), 1.34-1.29 (2H, m, $\left.-\mathrm{CH}_{2^{-}} \times 2\right)$; HRMS (negative mode); Found: $m / z$ 939.2057 $[\mathrm{M}-\mathrm{Na}]^{-}$, Calcd for $\mathrm{C}_{34} \mathrm{H}_{50} \mathrm{~N}_{3} \mathrm{O}_{20} \mathrm{~S}_{3}$ : 939.2053 .

\section{Click here to remove instruction text..}




\section{Graphical Abstract}

To create your abstract, type over the instructions in the template box below.

Fonts or abstract dimensions should not be changed or altered.

Towards the construction of dermatan sulfate (DS)

Leave this area blank for abstract info.

partial disaccharide library: efficient synthesis of

building blocks, common intermediate, and ligand

conjugate of type-B DS disaccharide

Yuhei Kaitsubata, Rikiya Aramaki, Kyosuke Nishioka, Masahiro Wakao,* Yasuo Suda

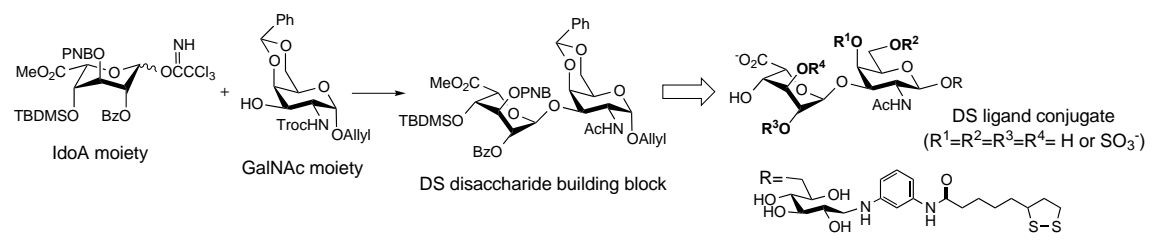

